\title{
Health-related quality of life of firefighters and police officers 8.5 years after the air disaster in Amsterdam
}

\author{
Pauline Slottje $\cdot$ Jos W. R. Twisk $\cdot$ Nynke Smidt $\cdot$ \\ Anja C. Huizink · Anke B. Witteveen · \\ Willem van Mechelen · Tjabe Smid
}

Published online: 6 March 2007

(C) Springer Science+Business Media B.V. 2007

Erratum to: Qual Life Res (2007) 16: 239-252

DOI 10.1007/s11136-006-9006-2

The first author's first name was incorrectly published in the original.

The online version of the original article can be found at http:// dx.doi.org/10.1007/s11136-006-9006-2

P. Slottje · J. W. R. Twisk · N. Smidt · A. C. Huizink ·

A. B. Witteveen - W. van Mechelen - T. Smid

EMGO Institute, VU University Medical Center,

Amsterdam, the Netherlands

P. Slottje - A. C. Huizink - W. van Mechelen - T. Smid Department of Public and Occupational Health, VU

University Medical Center, Amsterdam,

the Netherlands

A. C. Huizink

Department of Child and Adolescent Psychiatry, Erasmus

Medical Center, Rotterdam, the Netherlands

A. B. Witteveen

Department of Medical Psychology, VU University Medical Center, Amsterdam, the Netherlands

T. Smid

J. W. R. Twisk

Department of Clinical Epidemiology and Biostatistics, VU

University Medical Center, Amsterdam, the Netherlands

N. Smidt

Department of Clinical Epidemiology and Biostatistics,

Academic Medical Center, University of Amsterdam,

KLM Health Services, Schiphol, the Netherlands

T. Smid $(\bowtie)$

Department of Public and Occupational Health, VU

University Medical Center, EMGO Institute, Van der

Boechorststraat 7, 1081 BT Amsterdam, the Netherlands

e-mail: t.smid@vumc.nl 